\title{
The complexes of zinc, copper and manganese present in ryegrass
}

\author{
BY I. BREMNER \\ Rowett Research Institute, Bucksburn, Aberdeen \\ AND A. H. KNIGHT \\ Macaulay Institute for Soil Research, Craigiebuckler, Aberdeen
}

(Received 27 June 1969-Accepted 20 October 1969)

\begin{abstract}
I. The nature of the complexes of zinc, manganese and copper which occur in ryegrass has been examined as part of a study of the availability of these metals to ruminants.

2. Ryegrass labelled with ${ }^{65} \mathrm{Zn}$ was produced by water culture. A large proportion of the $\mathrm{Zn}$ could be extracted with aqueous ethanol and with water. The remainder of the $\mathrm{Zn}$ was liberated on peptic digestion and on treatment with a fungal cellulase.

3. The aqueous ethanolic extract was examined by a combination of gel filtration and thin-layer chromatographic and electrophoretic techniques. The results showed the presence of closely related complexes of $\mathrm{Zn}$ of low molecular weight. These were of limited stability and their behaviour was dependent on $\mathrm{pH}$.

4. The value of electrophoresis in free solution as a fractionation technique for the soluble forms of $\mathrm{Cu}, \mathrm{Zn}$ and $\mathrm{Mn}$ from ryegrass was demonstrated. Soluble $\mathrm{Mn}$ from was found to exist in a single cationic, perhaps non-complexed form, whereas several anionic $\mathrm{Cu}$ and $\mathrm{Zn}$ complexes were present in closely related forms.
\end{abstract}

The nature of the dietary components influencing the utilization of trace elements by animals is largely unknown. In consequence trace-element requirements are poorly defined and many discrepancies exist between statements of what constitutes an adequate or inadequate dietary concentration. In conditioned deficiency states, although the dietary concentration of the particular element would normally be regarded as adequate, unknown factors often operate to reduce the availability of the element to the animal. This reduction in availability may be the result of interactions between metals, as between copper and molybdenum, or of the formation of some insoluble complex of the element in the gut, such as zinc-phytate. All cases of conditioned trace-element deficiency cannot however be explained in these ways, and it has often been suggested that the form in which the element is present in the diet governs to a large extent its availability to the animal.

Very little is known of the forms in which trace elements occur in plants, and therefore, as a first step in attempting to assess the importance of dietary metal complexes in governing the availability of trace elements, the nature and properties of the complexes of zinc, manganese and copper in ryegrass have been investigated. The significance of these findings to the possible behaviour of the metals in the gastro-intestinal tract is discussed. 
EXPERIMENTAL

\section{Production of ryegrass}

All ryegrass used in this study was grown under controlled heating and lighting conditions in water culture, using a nutrient solution based on that of Hoagland \& Arnon (1938). When ${ }^{65} \mathrm{Zn}$-labelled ryegrass was required, $\left[{ }^{65} \mathrm{Zn}^{8} \mathrm{Cl}_{\mathbf{2}}\right.$ (Radiochemical Centre, Amersham, Bucks; specific activity $500 \mathrm{mc} / \mathrm{g} \mathrm{Zn}$ ) was added to the nutrient solution. The specific activity of the nutrient solution was generally $50 \mu \mathrm{c} / 1$. The ryegrass had a specific activity of $\mathrm{I} \cdot 5 \mu \mathrm{c} / \mathrm{g}$ fresh matter (FM), equivalent to an activity of about $300 \mathrm{mc} / \mathrm{g} \mathrm{Zn}$. The concentrations of $\mathrm{Zn}, \mathrm{Cu}$ and $\mathrm{Mn}$ in the ryegrass were $\mathbf{5}^{\mathbf{2}}$, I 8 and $89 \mu \mathrm{g} / \mathrm{g}$ dry matter (DM) respectively. The ryegrass was harvested at intervals of about 3 weeks, when it was IO-I $5 \mathrm{~cm}$ high, and was stored at $-20^{\circ}$ immediately. The nutrient solution was replenished at regular intervals throughout the growth period. Ryegrass was grown with a range of specific activities of ${ }^{65} \mathrm{Zn}$ in the nutrient solution up to fifteen times that quoted above. As growth, judged by yield and appearance, was normal at all these levels it was assumed that no radiation damage had occurred.

\section{Extraction of ryegrass}

Ethanol and aqueous extracts. The ryegrass ( $10 \mathrm{~g}$ ) was cut into small segments and extracted sequentially with $80 \%(\mathrm{v} / \mathrm{v})$ ethanol $(5 \times 100 \mathrm{ml})$ and distilled water $(3 \times 100 \mathrm{ml})$, using an Atomix blender for initial homogenization of the grass. The extracts were collected by filtration through cheesecloth. Samples $(2 \mathrm{ml})$ of the extracts were taken for ${ }^{65} \mathrm{Zn}$ counting and the remainder of the appropriate filtrates were combined and concentrated by rotary evaporation under reduced pressure at $40^{\circ}$. When the volumes had been reduced to about $50 \mathrm{ml}$, the concentrated solutions were extracted with diethyl ether $(2 \times 50 \mathrm{ml})$. The ether solutions were essentially non-radioactive and were discarded. The aqueous solutions were then centrifuged and the centrifuggates stored at $-20^{\circ}$. The water-insoluble residue was washed with ethanol and dried in a desiccator.

Extraction of water-insoluble residue. (a) A sample ( $2 \mathrm{~g}$ ) of the residue was extracted with $80 \%(\mathrm{w} / \mathrm{v})$ phenol-water $(4 \circ \mathrm{ml})$ at room temperature for 2 days. The extract was collected by filtration and suitable samples of filtrate and residue were taken for counting.

(b) A sample ( $\mathrm{I} g$ ) of the residue was extracted at $100^{\circ}$ for $\mathrm{I} h$ with a solution (I00 $\mathrm{ml}$ ) containing sodium lauryl sulphate $(3 \mathrm{~g})$, in borax-phosphate buffer $(\mathrm{pH} 7 \cdot 0$, $0.02 \mathrm{M}$ ). The mixture was then filtered and suitable samples of the residue and filtrate were counted. The remainder of the filtrate was dialysed against running water for $16 \mathrm{~h}$, whereupon a sample of the non-diffusable fraction was taken for counting.

(c) A sample ( $\mathrm{g}$ ) of the residue was incubated at $37^{\circ}$ for $64 \mathrm{~h}$ with a solution of trypsin (Boehringer, Mannheim, Germany; $20 \mathrm{mg}$ ) in $0.0 \mathrm{I} \mathrm{M}$-tris- $\mathrm{HCl}$ buffer ( $\mathrm{pH} 7 \cdot 4 ; \mathrm{I} \circ \mathrm{ml}$ ). Blank extractions were also carried out in the absence of the enzymes. The mixtures were filtered and suitable samples counted.

(d) A sample $(500 \mathrm{mg})$ of the residue was extracted at $37^{\circ}$ for $64 \mathrm{~h}$ with a solution 
of pepsin ( $500 \mathrm{mg}$ ) in $0.0 \mathrm{I} \mathrm{M}$-sodium acetate buffer $\left(\mathrm{pH}_{4} \cdot 0 ; 25 \mathrm{ml}\right)$. A blank extraction was also carried out. The mixtures were filtered and suitable samples of residue and filtrate were counted.

(e) A sample of the residue $(500 \mathrm{mg}$ ) was extracted with Hemicellulase (KochLight Laboratories, Colnbrook; $20 \mathrm{mg}$ ) in water ( $10 \mathrm{ml}$ ) at $37^{\circ}$ for $64 \mathrm{~h}$. The mixture was filtered and suitable samples of residue and filtrate were counted.

(f) A solution $(5 \mathrm{ml})$ of a crude cellulase obtained from a culture filtrate of Trichoderma koningii was diluted with $0.2 \mathrm{M}$-sodium acetate buffer $\left(\mathrm{pH}_{4} \cdot 8,45 \mathrm{ml}\right)$. It was then purified by extraction with $0.2 \%(\mathrm{w} / \mathrm{v})$ dithizone in $\mathrm{CCl}_{4}$. A sample $(500 \mathrm{mg})$ of the water-insoluble residue was treated with this enzyme preparation $(3 \circ \mathrm{ml})$ at $45^{\circ}$ for 2 days, whereupon the mixture was filtered and suitable samples of residue and filtrate were taken for counting.

\section{Analytical procedures}

Analysis of samples. Analyses for $\mathrm{Zn}, \mathrm{Cu}$ and $\mathrm{Mn}$ were carried out by atomic absorption spectroscopy. Dilute aqueous solutions were sprayed directly, but all other samples were first digested with mineral acids. Phosphorus was estimated by the automated method of Young ( 1966 ). Detection of ${ }^{65} \mathrm{Zn}$ after thin-layer chromatography or electrophoresis was by autoradiography on Ilford 'Ilflex' X-ray film. Radioisotope counting was carried out in the Packard Series 5000 Auto-Gamma Spectrometer.

Thin-layer chromatography $(T L C)$ and electrophoresis. Separations were carried out on layers $(0.5 \mathrm{~mm}$ ) of MN $300 \mathrm{G}$ cellulose powder (Macherey, Nagel and Co., Düren, Germany). Solvents used for TLC were phenol-water $(3: 1, \mathrm{v} / \mathrm{v})$ and isopropanolwater $(65: 35, v / v)$. Electrophoretic separatinos were carried out at a voltage of approximately $8 \mathrm{~V} / \mathrm{cm}$. Wicks of Whatman $3 \mathrm{MM}$ paper were used to connect the plates with the buffer solutions. The following ranges of buffers $(0.2 \mathrm{M})$ were used: sodium acetate $\left(\mathrm{pH} 4^{\circ} 0-5^{\circ} 0\right)$, tris $-\mathrm{HCl}\left(\mathrm{pH} 7^{\cdot 2} \cdot 7^{\cdot 8}\right)$ and sodium barbiturate $\left(\mathrm{pH} 7 \cdot 4^{-7} \cdot 8\right)$.

Gel filtration. Separations were carried out on columns, usually $85 \times 2.5 \mathrm{~cm}$ or $45 \times 2.5 \mathrm{~cm}$, of Sephadex G-15 (Pharmacia Ltd, Uppsala, Sweden) or Biogel P-2 (Biorad Laboratories, Ltd, Richmond, California), with chloroform-saturated water as eluant. Occasionally $0.1 \mathrm{M}-\mathrm{NaCl}$ or $0.01 \mathrm{M}$-tris- $\mathrm{HCl}(\mathrm{pH} 7.9)$ was used as eluant, in which event the column was preequilibrated with these solutions. Columns were washed with $0 \cdot \mathrm{I} \mathrm{N}-\mathrm{HCl}, \mathrm{O} \cdot \mathrm{I} \mathrm{M}-\mathrm{NaCl}$ and $\mathrm{H}_{2} \mathrm{O}$ between separations in order to remove adsorbed metal ions. Appropriate fractions $(5-10 \mathrm{ml})$ were collected automatically and were analysed for ${ }^{65} \mathrm{Zn}$ or for other components by standard techniques.

Continuous-flow electrophoresis. Electrophoretic separations of the $80 \%(\mathrm{v} / \mathrm{v})$ ethanolic extract of the ryegrass were carried out on the continuous-flow high-voltage electrophoresis apparatus of Hannig (Elphor VaPI, Drs Bender and Hobein Grubh, Lindwermstr. $7 \mathrm{I}$, Munich). As no support medium is required in this apparatus, the sample being carried in a thin film of buffer, electroendosmotic and adsorption effects are consequently eliminated. All buffers were purified before use either by dithizone treatment or by passage through a column of Chelex 100 resin (Biorad Laboratories Ltd). Zn concentrations in the cuvette buffers were always less than $\circ .0 \mathrm{r} \mu \mathrm{g} / \mathrm{ml}$ and $\mathrm{Cu}$ and $\mathrm{Mn}$ concentrations were even smaller. The following buffers 
were used: tris-acetate, $0.2 \mathrm{M}$ in electrode chambers, $0.04 \mathrm{M}$ in cuvette, $\mathrm{pH} 7 \cdot 2,7.5$ and 7.8 ; sodium hydroxide-acetic acid, $0.2 \mathrm{M}$ and $0.03 \mathrm{M}$ in electrode chambers and cuvette respectively, $\mathrm{pH} 5.4$. The lateral displacement of the various components from the introduction point was controlled by variation of the buffer flow rates. The applied voltage was usually about $2000 \mathrm{~V}$, equivalent to $40 \mathrm{~V} / \mathrm{cm}$ at a current of $\mathrm{I}_{5} \mathrm{O}-$ $200 \mathrm{~mA}$. The through-put time for the sample within the cuvette was usually $5^{\circ-}$ I00 min. Forty-eight fractions were collected automatically. A certain amount of contaminant metal, especially $\mathrm{Zn}$, circulated in the buffers. This probably originated from the plastic tubing but, as it was found to be concentrated in fractions $1-4$ and $46-48$, i.e. in the immediate vicinity of the electrode chambers, it did not prove to be too great a hazard. Quantitative recovery of the applied sample was readily obtained, provided suitable blank corrections were made for the contaminants present.

\section{RESULTS}

\section{Experiments on ${ }^{65} \mathrm{Zn}$-labelled ryegrass}

Extraction of ryegrass. Some differences were noted in the solubilities of the ${ }^{65} \mathrm{Zn}$ in the first and second harvests of the ryegrass. On sequential extraction first with $80 \%(\mathrm{v} / \mathrm{v})$ aqueous ethanol and later with water, the proportions of ${ }^{65} \mathrm{Zn}$ removed were 50 and $15 \%$ respectively for the first harvest and 35 and $30 \%$ for the second harvest. The ${ }^{65} \mathrm{Zn}$ content of the ryegrass was the same for both harvests. Subsequent extraction of the water-insoluble residue with $80 \%$ phenol-water or $3 \%$ sodium lauryl sulphate at $\mathrm{pH} 7 \cdot 0$, both of which are used as solvents for proteins, removed less than $10 \%$ of the residual $\mathrm{Zn}$, i.e. less than $3 \%$ of the $\mathrm{Zn}$ in the ryegrass. Over $75 \%$ of the $\mathrm{Zn}$ dissolved by the neutral detergent did not diffuse through Visking tubing. Tryptic digestion at $\mathrm{pH} 74^{4}$ did not dissolve significant amounts of ${ }^{65} \mathrm{Zn}$, but digestion with pepsin in acetate buffer at $\mathrm{pH}_{4} \cdot{ }^{\circ}$ dissolved $22 \%$ of the $\mathrm{Zn}$ present in the ryegrass. Part of this dissolution was, however, due to the action of the buffer and only I $\mathrm{\%} \%$ of the $\mathrm{Zn}$ in the plant was apparently dissolved as a direct result of proteolytic hydrolysis.

Enzymic hydrolysis of the water-insoluble residue with the crude cellulase preparation resulted in almost complete dissolution of the residual $\mathrm{Zn}$. Only $2 \%$ of the $\mathrm{Zn}$ in the original ryegrass was associated with the insoluble material after this hydrolysis. In contrast, digestion of the original water-insoluble residue with a commercial Hemicellulase preparation did not release $\mathrm{Zn}$ into solution.

Gel filtration studies on $80 \%$ ethanol extract of ryegrass. It was established on the basis of gel filtration studies on Sephadex G-I 5 and on Biogel $\mathrm{P}-2$ that the ${ }^{65} \mathrm{Zn}$ present in the aqueous ethanolic extract of ryegrass, and therefore at least half of the $\mathrm{Zn}$ in the plant, was not excluded by the gel particles and was therefore of a molecular weight less than 1500. A typical separation is shown in Fig. I. The $\mathrm{Zn}$ was eluted ahead of the main amino acids and also of phenolic and carbohydrate compounds (not shown). The skewness of the peak indicates a lack of homogeneity; this was confirmed by subsequent thin-layer chromatographic examination of the extract.

The elution volume of the complex was dependent on the $\mathrm{pH}$ of the sample and of 
the eluant. Elution of the $\mathrm{Zn}$ with $0.0 \mathrm{M} \mathrm{M}$-veronal buffer at $\mathrm{pH} 7 \cdot 4$ resulted in a reduction in elution volume from 260 to $190 \mathrm{ml}$. Recoveries of ${ }^{65} \mathrm{Zn}$ from the columns were variable $(50-100 \%)$, especially if the sample had been stored for some time, even at $-20^{\circ}$. Under the conditions generally used for gel filtration, non-complexed $\mathrm{Zn}$ was found to be adsorbed on the Sephadex.

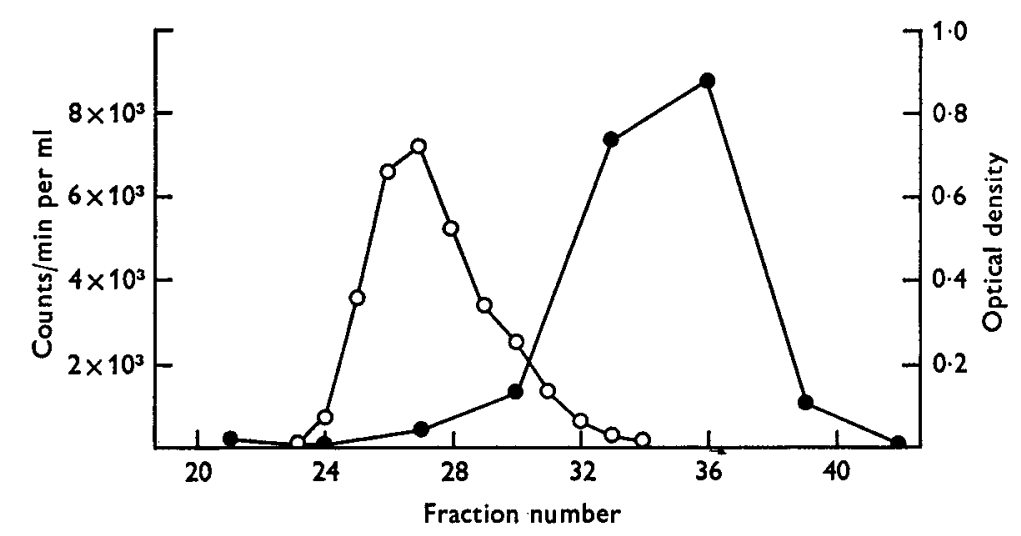

Fig. 1. Typical separation of $80 \%$ ethanol extract of ${ }^{65} \mathrm{Zn}$-labelled ryegrass on Sephadex G-I 5 with water as eluent. Counts/min of ${ }^{65} \mathrm{Zn}(O)$ and optical densities $(0)$ obtained on $\alpha$-amino nitrogen estimations are shown.

Thin-layer chromatographic examination of $80 \%(v / v)$ ethanol extract. Chromatographic examination of the $80 \%(\mathrm{v} / \mathrm{v})$ ethanol extract on cellulose thin layers revealed the presence of at least three $\mathrm{Zn}$-containing components in addition to the material which remained on the starting line. The latter was probably ionic $\mathrm{Zn}$. The relative proportions of all these components were variable, partly as a result of 'tailing' of the bands on the chromatograms, but it appeared that the time of harvest of the ryegrass and the storage time of the extract might have influenced the proportions. The three components had $R_{F}$ values in phenol-water solvent of $0 \cdot 10,0.45$, and 0.65 and they occurred in the approximate ratio $2: 3: 6$ immediately after extraction. Attempts at isolation of the complexes by preparative chromatography were not successful, as some interchange of the complexes seemed to occur. Re-examination of the isolated ' 0.65 ' component showed that conversion to the ' 0.10 ' component and other indeterminate products had taken place.

It was found that the main complexes (' 0.45 ' and ' 0.65 ') differed slightly in their elution volumes from a column of Biogel $\mathrm{P}-2$, suggesting some difference in the molecular size of the complexes. Although only one ${ }^{65} \mathrm{Zn}$ peak was detected in the eluate of the column (Fig. 2), subsequent TLC examination of the individual fractions revealed that the ' 0.65 ' component was eluted ahead of the ' 0.45 ' component.

Thin-layer electrophoretic examination of $80 \%(v / v)$ ethanol extract. Electrophoretic examination of the ethanolic extract on cellulose layers confirmed the presence of several complexed forms of $\mathrm{Zn}$ in the extract. The mobilities of these complexes were dependent on both the $\mathrm{pH}$ and the nature of the buffer solutions used, although these were chosen so as to have minimum interaction with the metal. The $\mathrm{Zn}$ complexes 
tended to be cationic or near neutral at the lower $\mathrm{pH}$ values and anionic at higher values. At high $\mathrm{pH}$ values especially, a minor anionic $\mathrm{Zn}$ complex which was electrophoretically indistinguishable from Zn-EDTA was detected. The possible origin of this fraction is considered on p. 288. In no instance did any of the $\mathrm{Zn}$ detected have the same mobility as ionic $\mathrm{Zn}$, although in acetate buffer at $\mathrm{pH}_{4.5}$ all the $\mathrm{Zn}$ was present in a cationic form with a mobility only slightly less than that of ionic $\mathrm{Zn}$. Prolonged separations greatly improved the resolution obtained, as can be seen in P1. I.

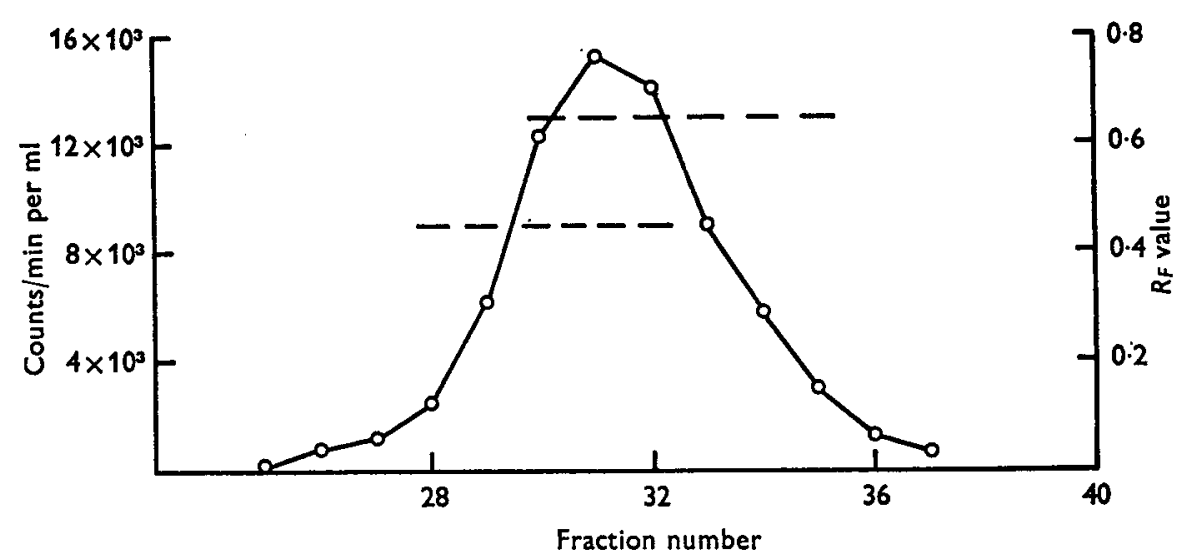

Fig. 2. Separation of $80 \%$ ethanol extract of ${ }^{65} \mathrm{Zn}$-labelled ryegrass on Biogel $\mathrm{P}-2$ column. The counts/min per $\mathrm{ml}(O)$ of the ${ }^{65} \mathrm{Zn}$ in the individual fractions are shown. In addition, the $R_{F}$ values of the ${ }^{65} \mathrm{Zn}$ complexes present in each of these fractions, as determined by TLC separations in phenol-water as solvent, are shown by the horizontal bars.

Gel filtration and chromatographic examination of aqueous extract. The complexes of $\mathrm{Zn}$ present in the aqueous extract prepared after ethanol-water extraction of the ryegrass were difficult to analyse because of their apparent instability. However, on gel filtration on Sephadex $\mathrm{G}-\mathrm{I} 5$ at least some of the ${ }^{65} \mathrm{Zn}$ was found to be excluded from the gel, but the total recovery from the column was only about $20 \%$. This fraction must be of molecular weight greater than 1500 and thus would probably contain the $\mathrm{Zn}$-containing enzymes present in the ryegrass. Thin-layer chromatographic examination of the extract was not entirely satisfactory, but the main complexes extracted with $80 \%$ ethanol were shown to be present along with some non-mobile $\mathrm{Zn}$. Storage of this extract, even at $-20^{\circ}$, frequently resulted in precipitation of the ${ }^{65} \mathrm{Zn}$ in some unknown form.

\section{Experiments with non-radioactive ryegrass}

Electrophoretic examination of $80 \%(v / v)$ ethanol extract. Successful fractionations of the aqueous ethanolic extract of ryegrass were obtained on the Hannig continuousflow high-voltage electrophoresis apparatus. Typical separations are shown in Figs. 3, 4 and 6 , using tris-acetate $\left(\mathrm{pH}_{7 \cdot 5}\right)$ and sodium acetate $\left(\mathrm{pH}_{5 \cdot 4}\right)$ buffers. At $\mathrm{pH} 7 \cdot 5$ there was little difference in the separation pattern of the several $\mathrm{Zn}$ and $\mathrm{Cu}$ complexes, except for the occurrence of an additional $\mathrm{Zn}$ complex (A) of much greater mobility 
(Fig. 3). Both the $\mathrm{Cu}$ and $\mathrm{Zn}$ were present only in anionic form and no component was detected with the same mobility as the non-complexed metal. Manganese, however, appeared to be present only in cationic and probably non-complexed form. It was found that the $\mathrm{Zn}$ complex $\mathrm{A}$ was almost completely removed when the electrophoretic separation was carried out on the main portion of the $\mathrm{Zn}$ peak isolated after gel filtration of the extract on Sephadex G-I 5 (corresponding to fractions 24 and 27 in Fig. 1 ). This suggests that the $\mathrm{Zn}$ complex of lower molecular weight in the extract corresponds to that with the greatest electrophoretic mobility.


Fig. 4

Fig. 3. Electrophoretic separation of $80 \%$ ethanol extract of ryegrass in tris-acetate buffer at $\mathrm{pH} 7 \cdot 5$. Concentrations of $\mathrm{Zn}(\mathrm{O})$ and $\mathrm{Cu}(\bullet)$ are shown. The symbols $(+), \downarrow$ and $(-)$ refer to the anode, introduction point and cathode respectively. Fractions $A, B$ and $C$ refer to the combined tubes $3^{-6}, 5^{-2}$ I and $23-27$ respectively.

Fig. 4. Electrophoretic separation of $80 \%$ ethanol extract of ryegrass in tris-acetate buffer at $\mathrm{pH} 7 \cdot 5$. Concentrations of $\mathrm{P}(O)$ and the ratio of the optical densities at 280 and $260 \mathrm{~nm}(O)$ are shown. The symbols $(+), \downarrow,(-)$ refer to the anode, introduction point and cathode respectively.

Analyses of the fractions obtained after electrophoresis showed that $\mathrm{Zn}$ and $\mathrm{Cu}$ were being effectively separated from a large proportion of the organic components present in the extract, although u.v. absorbing material was associated with the slowermoving complexes. It was found, however, that the material associated with the peak of fraction B had a maximum absorption at $280 \mathrm{~nm}$ and that a plot of the ratio of the optical densities at $280 \mathrm{~nm}$ and $260 \mathrm{~nm}$ against tube number gave peaks which were associated with the trace-element peaks (Fig. 4). It may be that the compounds responsible for this u.v. absorption are the ligands binding the $\mathrm{Zn}$ or $\mathrm{Cu}$.

Zinc readily forms complexes with a wide range of phosphorus-containing compounds found in biological materials. Accordingly, the fractions collected after electrophoretic separation of the grass extract at $\mathrm{pH} 7.5$ were also analysed for $\mathrm{P}$. It can be seen (Fig. 4) that a major P component does in fact have a mobility identical to that of the mobile $\mathrm{Zn}$ complex A. The P:Zn ratio in this fraction was found, however, to be $45:$ I on a molar basis, making it unlikely that this association is significant. This was confirmed by subsequent examination of the complex A by gel filtration on Sephadex 
$\mathrm{G}-15$, using tris-acetate buffer $\left(\mathrm{pH}_{7} \cdot 5 ; 0.01 \mathrm{M}\right)$ as eluant. It was found that the $\mathrm{Zn}$ and $\mathrm{P}$ were clearly separated (Fig. $5 a$ ). The elution volume of the $\mathrm{Zn}$ from the column was the same as that noted for the $\mathrm{Zn}$ in the original extract, implying that the electrophoretic fractionation had not modified the properties of the complex.

Similar examination by gel filtration on Sephadex G-r 5 of the other $Z \mathbf{n}$ complexes $\mathrm{B}$ and $\mathrm{C}$ separated by electrophoresis at $\mathrm{pH} 7 \cdot 5$ confirmed the close association of $\mathrm{Cu}$



(a) Fraction number

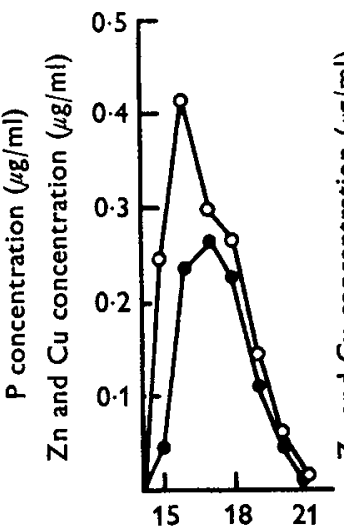

(b) Fraction number

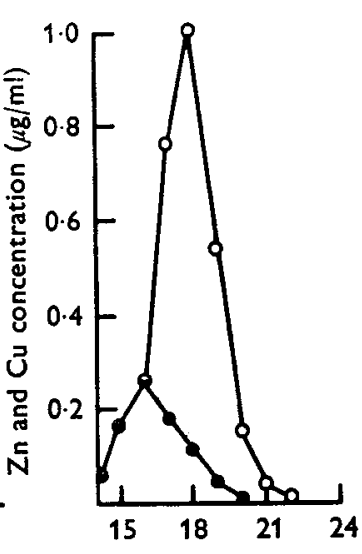

(c) Fraction number

Fig. 5. Separation on Sephadex G-1 5 of combined fractions collected after electrophoresis of $80 \%$ ethanol extract of ryegrass in tris-acetate buffer at $\mathrm{pH} 7.5$. (See Fig. 3.) (a) Fraction A shown in Fig. 3 : concentrations of $\mathrm{Zn}(O)$ and $\mathrm{P}(\Theta)$ are shown. (b) Fraction B shown in Fig. 3 : concentrations of $\mathrm{Zn}(\mathrm{O})$ and $\mathrm{Cu}(\odot)$ are shown. (c) Fraction $\mathrm{C}$ shown in Fig. 3 : concentrations of $\mathrm{Zn}(\mathrm{O})$ and $\mathrm{Cu}(\mathbf{O})$ are shown.



Fig. 6. Electrophoretic separation of $80 \%$ ethanol extract of ryegrass in acetate buffer at $\mathrm{pH}$ 5.4. Concentrations of $\mathrm{Zn}(O)$ and $\mathrm{Cu}(\odot)$ are shown. The symbols $(+), \downarrow$ and $(-)$ refer to the anode, introduction point and cathode respectively. 
and $\mathrm{Zn}$ at this $\mathrm{pH}$. The elution volumes of the two metals were very similar (Fig. $5 b$, c) and in some fractions the molar ratio of $\mathrm{Cu}: \mathrm{Zn}$ was close to $\mathrm{I}: \mathrm{I}$. However, as the recoveries of the metals from the columns were not always satisfactory, it is impossible to judge the full significance of this.

Electrophoretic examination of the $80 \%$ ethanol extract at $\mathrm{pH} 5.4$ in acetate buffer (Fig. 6) gave results which were similar in that at least three anionic $\mathrm{Zn}$ complexes were separated, including a minor one of relatively high mobility. The resolution was better than was obtained at higher $\mathrm{pH}$ values, but the mobilities were reduced. It was found that the $\mathrm{Cu}$ complexes could now be separated from the $\mathrm{Zn}$ and it appeared that two complexes of $\mathrm{Cu}$ were probably present. There were no indications of the presence of ionic $\mathrm{Cu}$ or $\mathrm{Zn}$, although it appeared that $\mathrm{Mn}$ was probably present only in this form.

\section{DISCUSSION}

Very little is known of the forms in which trace elements occur in plants. The presence of $\mathrm{Mn}$ in the leaves of several plants in an ether-soluble complex with galactosyldiglyceride, linoleic acid and 'flavine' has been reported (Udel'nova \& Boichenko, 1967) but less than $\mathrm{I} \%$ of the $\mathrm{Zn}, \mathrm{Cu}$ or $\mathrm{Mn}$ in ryegrass was found to be soluble in non-polar solvents. On the basis mainly of electrophoretic evidence Tiffin \& Brown (1962) and Tiffin ( 1966 ) have reported the presence of anionic complexes of $\mathrm{Fe}$ and hydroxy acids in the exudates of several plants. In sunflower, tomato, and cucumber the $\mathrm{Fe}$ appeared to be bound to citrate and in soya-bean possibly to malate and maleate. In tomato plant $\mathrm{Zn}$ and $\mathrm{Mn}$ were found to be present in cationic form on electrophoresis at $\mathrm{pH} 5.4$ and it was concluded that these metals were present in the exudate in non-complexed form (Tiffin, 1967). Similar findings have been reported for the $\mathrm{Zn}$ and $\mathrm{Mn}$ present in the exudate of soya-bean (Lingle, Tiffin \& Brown, I963). In sunflower exudate, however, it has been found that complexed and non-complexed forms of $\mathrm{Mn}$ and $\mathrm{Zn}$ can be detected on electrophoresis at $\mathrm{pH} 8.3$ (Höfner, I968).

Although exact identification of the forms in which the trace elements $\mathrm{Zn}, \mathrm{Cu}$ and $\mathrm{Mn}$ occur in ryegrass was not possible, all the evidence obtained suggests that large proportions of the soluble $\mathrm{Zn}$ and $\mathrm{Cu}$ are present in the form of closely related low molecular weight complexes, whereas the soluble $\mathrm{Mn}$ is present in cationic and probably non-complexed form. Over $60 \%$ of the $\mathrm{Zn}, \mathrm{Cu}$ and $\mathrm{Mn}$ could be removed by sequential extraction with aqueous ethanol and water. Complete extraction of the $80 \%$ ethanol-soluble $\mathrm{Zn}$ was difficult to achieve and it is possible that at least some of the subsequent aqueous extract contains $\mathrm{Zn}$ components identical with those in the ethanol extract. The aqueous extract also contained some $\mathrm{Zn}$ components of relatively high molecular weight and it is probable that these correspond at least in part to the metalloenzymes which are present in the plant. Gel filtration studies on a direct aqueous extract indicated that around $2 \%$ of the soluble $\mathrm{Zn}$ was in this form.

It has been reported that over $70 \%$ of the $\mathrm{Zn}$ in germinating maize tissue can be readily extracted with aqueous ethanol, M-sodium chloride and $0.05 \mathrm{M}$-sodium hydroxide and that less than half of this $\mathrm{Zn}$ is diffusible through dialysis tubing, the remainder probably being protein-bound (Diez-Altares \& Bornemisza, 1967). 
Rudakova (1963) has studied the binding of $\mathrm{Zn}$ and $\mathrm{Mn}$ to proteins in sugar-beet leaves and found it to be age-dependent. A correlation between the $\mathrm{Cu}$ and protein contents in several plants has been established, although this does not necessarily imply a chemical association (Rasheed \& Seeley, 1966). In the present work, it was found that removal of 'soluble' protein by extraction or tryptic digestion resulted in dissolution of only a small percentage of the total $\mathrm{Zn}$, whereas peptic digestion of the water-insoluble residue dissolved over $20 \%$ of the $\mathrm{Zn}$ in the plant, although half of this was a direct consequence of the acidic conditions used during peptic digestion. Insufficient information is available for any deductions to be made about the type of $\mathrm{Zn}$-protein association that exists in the plant, but it does seem probable on the basis of these results that peptic digestion in the digestive tract of animals could lead to the liberation of all but about $15 \%$ of the $\mathrm{Zn}$ present in ryegrass.

An involvement of the residual $\mathrm{Zn}$ with carbohydrates in the cell wall of the plant is suggested by the action of the fungal cellulase from Trichoderma koningii. Practically all the $\mathrm{Zn}$ was liberated by this treatment, only traces remaining associated with the lignin residue. This does not preclude the existence of some $\mathrm{Zn}$-lignin association, however, as it may be that the metal is involved in the lignin-cellulose matrix that has so often been postulated. As cellulolytic enzymes function in the rumen, it is probable that rumen fermentation could result in a similar liberation of the $\mathrm{Zn}$ from the ryegrass.

As was expected, control of $\mathrm{pH}$ was extremely important in the examination of the soluble complexes of these metals. The changes noted in electrophoretic mobility and in behaviour on gel filtration studies, with an increase in negative charge and in the size of the complexes with increase in $\mathrm{pH}$, are in accord with the known hydrolysis and polymerization reactions of metal chelates. The situation here is complicated by the extremely heterogenous nature of the solutions; changes in $\mathrm{pH}$ and in overall composition of the solution (as occur during a series of fractionation steps) can upset the equilibrium state in which they exist and can lead to interchange of ligands. Perrin ( 1965 ) has examined this problem in some detail, utilizing computer techniques for prediction of the types of complex present in mixtures containing different metals and chelating agents under varying conditions.

Comparison of the chromatographic and electrophoretic mobilities of several relatively stable complexes of amino acids and hydroxy acids did not reveal any obvious relationships with the mobilities of the natural complexes. The low concentration of metal present in the extracts made it impossible to identify the ligand on the chromatograms by spraying techniques. The small proportion of Zn-EDTA apparently separated in thin-layer electrophoretograms must have resulted from the inclusion of EDTA in the ryegrass nutrient culture solutions to maintain the Fe in soluble form. The close association of $\mathrm{Cu}$ and $\mathrm{Zn}$, especially at higher $\mathrm{pH}$ values, even after separation by electrophoresis and gel filtration is of interest in view of the known mutually antagonistic effects of these metals during their absorption (Van Campen \& Scaife, 1967; Van Campen, 1969) and subsequent ultilization (Suttle \& Mills, 1966) by animals.

Considerable evidence has been accumulated over recent years in support of the theory that chelates of low molecular weight are involved in the uptake and transport 
British Journal of Nutrition, Vol. 24, No. I

Plate I

$+$

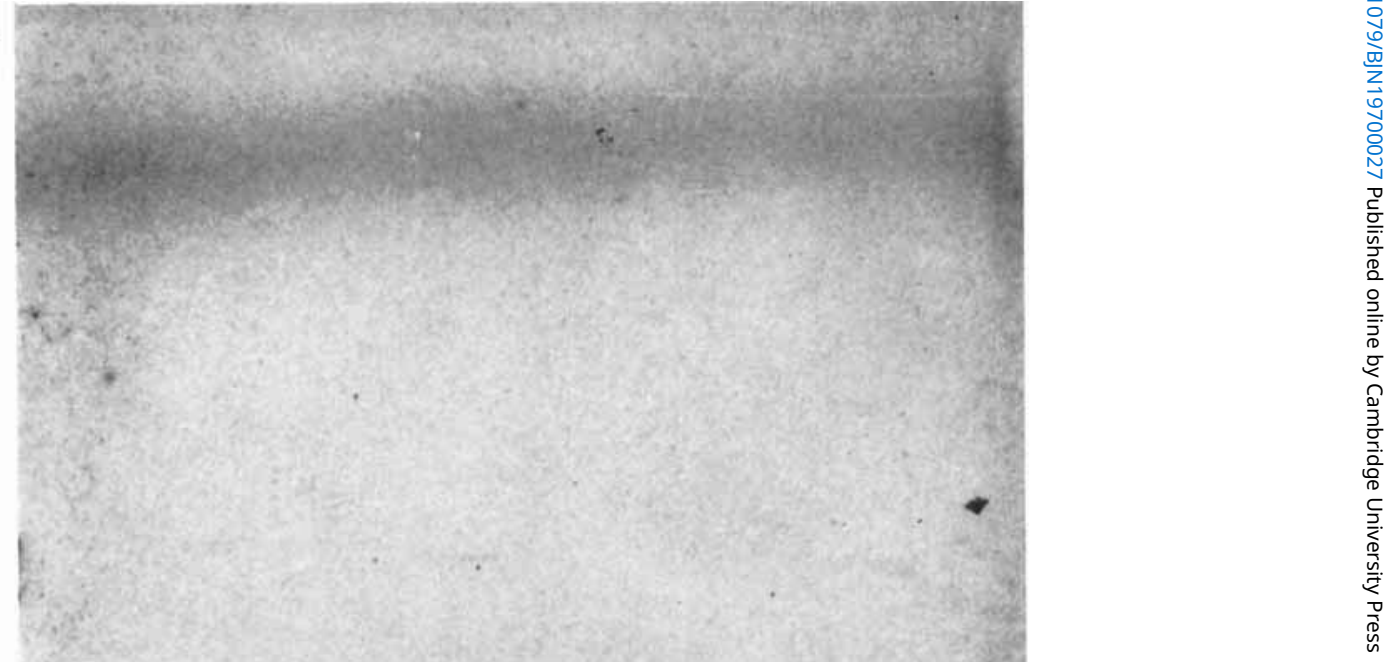


of metals in biological systems (Saltman, 1965). It has been suggested, for instance, that complexes of $\mathrm{Cu}$ and amino acids are involved in the uptake of $\mathrm{Cu}_{4}^{\circ}$ by liver (Harris \& Sass-Kortsak, 1967) and that complexes of $\mathrm{Fe}$ and serine and glycine"are involved in the uptake of $\mathrm{Fe}$ by the intestinal mucosa (Brown \& Rother, 1963). The capacity of different segments of gut to absorb trace elements has often been attributed at least in part to the change in $\mathrm{pH}$ which occurs along the alimentary tract (Kroe, Kaufman, Klavins \& Kinney, I 966 ). It may be that the $\mathrm{pH}$ effect operates through the changes in the properties of the complexed forms of the metal similar to those which have been noted here. It cannot be decided at this stage in the present investigation if the availability of trace elements to animals is likely to be related to their dietary form. It seems probable that less than about $15 \%$ of the metal would be in an insoluble form by the time the digesta had reached the acid conditions of the stomach.

Investigations on the fate of these complexes and of synthetic complexes during their passage down the gastro-intestinal tract are in progress. The results of these studies in which the techniques developed for the present work have been used will be incorporated in a forthcoming communication.

The cellulose preparation used in this investigation was kindly provided by $\mathrm{Dr} T$. M. Wood of the Rowett Research Institute. The ryegrass was grown at the Macaulay Institute for Soil Research, and all analytical work was done at the Rowett Research Institute. The technical assistance of Mr G. C. Smith is gratefully acknowledged.

\section{REFERENCES}

Brown, E. B. \& Rother, M. L. (1963). F. Lab. clin. Med. 62, 357.

Diez-Altares, C. \& Bornemisza, E. (1967). Pl. Soil 26, 175.

Harris, D. M. I. \& Sass-Kortsak, A. (1967). F. clin. Invest. 46, 659.

Hoagland, D. R. \& Arnon, D. I. (1938). Circ. Calif. agric. Exp. Stn no. 347, p. 1.

Höfner, W. (1968). Agrochimica 12, 140.

Kroe, D. J., Kaufman, N., Klavins, J. V. \& Kinney, T. D. (1966). Am. F. Physiol. 211, 414.

Lingle, J. C., Tiffin, L. O. \& Brown, J. C. (1963). Pl. Physiol., Lancaster 38, 71.

Perrin, D. D. (1965). Nature, Lond. 206, 170.

Rasheed, M. A. \& Seeley, R. C. (1966). Nature, Lond. 212, 644.

Rudakova, E. V. (1963). Mikroelementy v Zhizni Rast., Zhivotn. i Cheloveka, Akad. Nauk Ukr. SSR,

Inst. Fiziol. Rast., Tr. Koordinats. Soveshch. 1963, 53. Cf. Chem. Abstr. 64, 8642.

Saltman, P. (1965). F. chem. Educ. 42, 682.

Suttle, N. F. \& Mills, C. F. (1966). Br. Y. Nutr. 2o, I35.

Tiffin, L. O. (1 966). Pl. Physiol., Lancaster 4r, 510.

'Tiffin, L. O. (1967). Pl. Physiol., Lancaster 42, 1427.

Tiffin, L. O. \& Brown, J. C. (1962). Science, N.Y. 135, 3 I I.

Udel'nova, T. M. \& Boichenko, E. A. (I967). Biokhimiya 32, 779.

Van Campen, D. R. (1969). F. Nutr. 97, 104.

Van Campen, D. R. \& Scaife, P. U. (1967). F. Nutr. 92, 473.

Young, D. S. (1966). Y. clin. Path. r9, 397.

\section{EXPLANATION OF PLATE}

P1. I. Autoradiograph of thin-layer electrophoretic separation of $80 \%$ ethanol extract of ${ }^{65} \mathrm{Zn}$-labelled ryegrass (veronal buffer, $\mathrm{pH} 7 \cdot 8, I=0.05$ ). The origin is at the dotted line and movement is to the anode. 